\title{
Disjunctive Images in Renaissance Books
}

\author{
MARIAN ROTHSTEIN
}

Volumes that contain both pictures and words are normally referred to as illustrated books, and we are usually justified in assuming that the two modes provide complementary visual and verbal representation of the same material. But in the first century or so of printing, editions of histories, romances, vernacular versions of the classics, in fact, the kinds of books most likely to contain pictures, often appear with text and image sharing the page just as travellers in the period might have shared a bed at an inn: proximity, even contact, implies neither contamination nor intimate connections. To call such pictures illustrations would be to participate in etymological paradox since they cannot be said to shed light on the text they accompany. They will be referred to here as "disjunctive pictures." The discussion that follows examines some of the questions raised by the presence of disjunctive pictures in early printed books. ${ }^{1}$

Scholars have noted-generally in passing-the phenomenon of the disjunctive picture. It tends to be treated either with benign neglect or malicious interference. Some scholars note as a neutral fact that picture and text appear unrelated; more generally a generic link-battle scene for joust in text-is considered satisfactory explanation for the choice and placement of a woodcut. Eisenstein, noting the "notoriously inappropriate uses to which many woodcuts and engravings were put," does not perceive this as defining a problem, and categorizes them simply as errors. ${ }^{2}$ Ong has urged that the picture be understood as relief from the labors of the text, a point of view that might easily require that one consider a disjunctive picture functionally superior to an illustration. ${ }^{3}$ One immediate difficulty with this assumption is that, rather than decorating the pages of philosophical or legal treatises, disjunctive pictures tend to accompany texts that themselves were considered to have an element of recreation. ${ }^{4}$ It has been suggested that a major function of pictures may have been to help the reader find his place on a page crowded with print, in volumes that admittedly are rarely properly paginated. ${ }^{5}$ This would be more convincing if a given woodcut did not so often appear three, five or more times in the same volume. ${ }^{6}$ Others

Renaissance and Reformation / Renaissance et Réforme, XXVI, 2 (1990) 101 
have attempted to forge links between image and text by alleging allegory or typology when the text itself shows no sign of such thought. ${ }^{7}$ These diverse responses all share the same disadvantage: by dismissing questions implicitly posed by the use of disjunctive pictures, they block broader consideration of the issue. It is time to turn to some of these questions.

Any investigation in the history of the book is complicated by the fact that books are at once material, intellectual, and aesthetic objects. The forces contributing to the presence of disjunctive pictures may come from any of these aspects of the book. What kinds of economic factors might have shaped a publisher's decision to include pictures in a given volume? Did books with pictures have inherently greater prestige or a larger potential audience? Were pictures used to accommodate illiterates or sub-literates sharing the households of readers? What expectations did the book-user bring to pictures found within a volume? How were narrative pictures, which frequently contain a diachronic series of scenes, "read"? 8 Are there other contemporary manifestations that are similarly disjunctive or fragmenting, and that might shed light on the problem? These are some of the questions implied in an investigation of disjunctive pictures in early printed books.

Woodcuts are the most usual source of images in early printed books. ${ }^{9}$ Some understanding of the production and modes of use of woodblocks is relevant to our subject. With notable exceptions, they tend to be anonymous, corporate productions. A printed image is the end result of the work of a designer who drew a picture and a cutter who incised the block. In the history of book decoration, we seldom have any way of knowing who they were. ${ }^{10}$ Making any kind of visual census is greatly complicated by the fact that woodcut blocks could readily be copied, so that a given image might theoretically be reproduced almost indefinitely. Details were easy to remove by cutting away any unwanted raised (printing) areas of the block; they could be added with slightly more effort and skill by carefully removing a plug of carved wood from any part of a block and replacing it with another, differently carved. Blocks could also be changed by sawing off sections, leaving the bulk of the block to go on to another career, or, less often, producing two useable blocks from one. In short, the woodcut offered considerable and often realized flexibility. Moreover, woodblocks were durable objects. The world of the early printed book generally showed a strong reluctance to discard functional physical objects. Adult clothing was passed on to servants or, avoiding the more severely worn portions, cut down to fit children. Eventually it was used as rags, and the cotton or linen scraps finally sold to the ragman, thence to the papermaker, and next to the printer where the rags became books whose pages may still be fresh 
today, or which may have passed on to strengthen the spines of other books or wrap small objects or serve in the privy before finally disappearing. Publishers may well have applied the same mentality to woodcuts. They certainly did sometimes use woodcut blocks until they were too worn to produce a recognizable image. ${ }^{11}$ This is an impulse to be reckoned with, but alone it is not enough to account for disjunctive pictures.

Sometimes woodcut blocks' careers seem to have been arbitrarily determined by the printers or more often publishers who owned them. La Mer des Histoires, a popular history, contains a description of the baptism of Clovis. There is an accompanying woodcut (Fig. 1) showing on the left the actual baptism, and on the right the events leading to it: the battle of Tolbiac, the miraculous dove bringing Saint Rémy the holy chrism, the Christian faith of Clovis' wife Clothilde. This block was used several times in Le Rouge's 1489 edition. One might expect its appearance at moments that are in some way analogous to the baptism of Clovis; instead it reappears, for example, at the account of the death of Charles le bel, which deals neither with conversions nor battles won.

Another large block in the same edition of La Mer des histoires reappears three years later in Antoine Verard's edition of Josephus' De la Guerre Judaïque (1492), and then annually for the next three years in new editions of the Chroniques de France (1493), Lancelot du Lac (1494), and Le Mirouer historial (1495) (Fig. 2), all published by the same Verard, who was very likely the greatest publisher of books with woodcuts in France as the fifteenth century gave way to the sixteenth. The woodcut in question was used by Verard at least twice more, in 1509 in a translation of the Aeneid, as well as in an undated Bible historiee. The repeated use of a single complex and striking composition in at least seven books, all folio, and therefore all making a certain implicit claim to luxury, is curious enough, but what we have here is not a case of simple reuse. Although the picture is not necessarily used in an illustrative relation to the texts, the central figure in the foreground undergoes adaptive alterations. The man who is portrayed as a bishop in Josephus has become a king in the Chroniques and a knight in the Lancelot, suggesting that a deliberate effort was being made to coordinate verbal and visual themes (Fig. 3).

On careful consideration, the plot thickens. The king who appeared first 1493, reappears in 1495 and 1509.12 Between these dates, in 1494, he had been changed to a knight. Two suppositions are possible. There may have been two blocks, one a copy of the original block varying only in the headgear. Or there might be only one block, a section of which was carefully sawn out. This hole could then be filled with the original plug or with another 
104 / Renaissance and Reformation

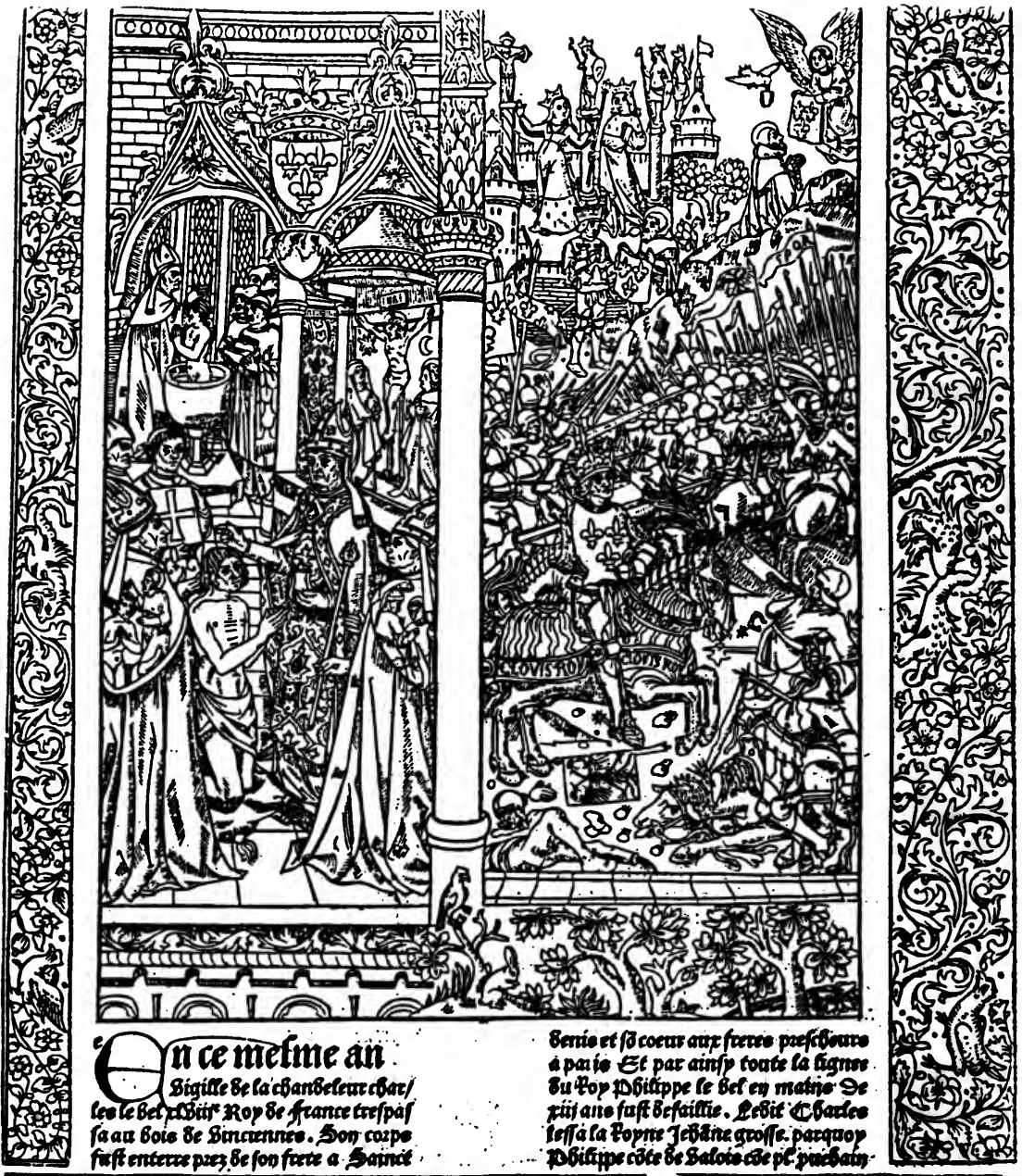
167\%

Figure 1

La Mer des Hystoires (Paris: Le Rouge, 1489) reproduced from Ponomarenko \& Roussel, op. cit. fig. 405. 


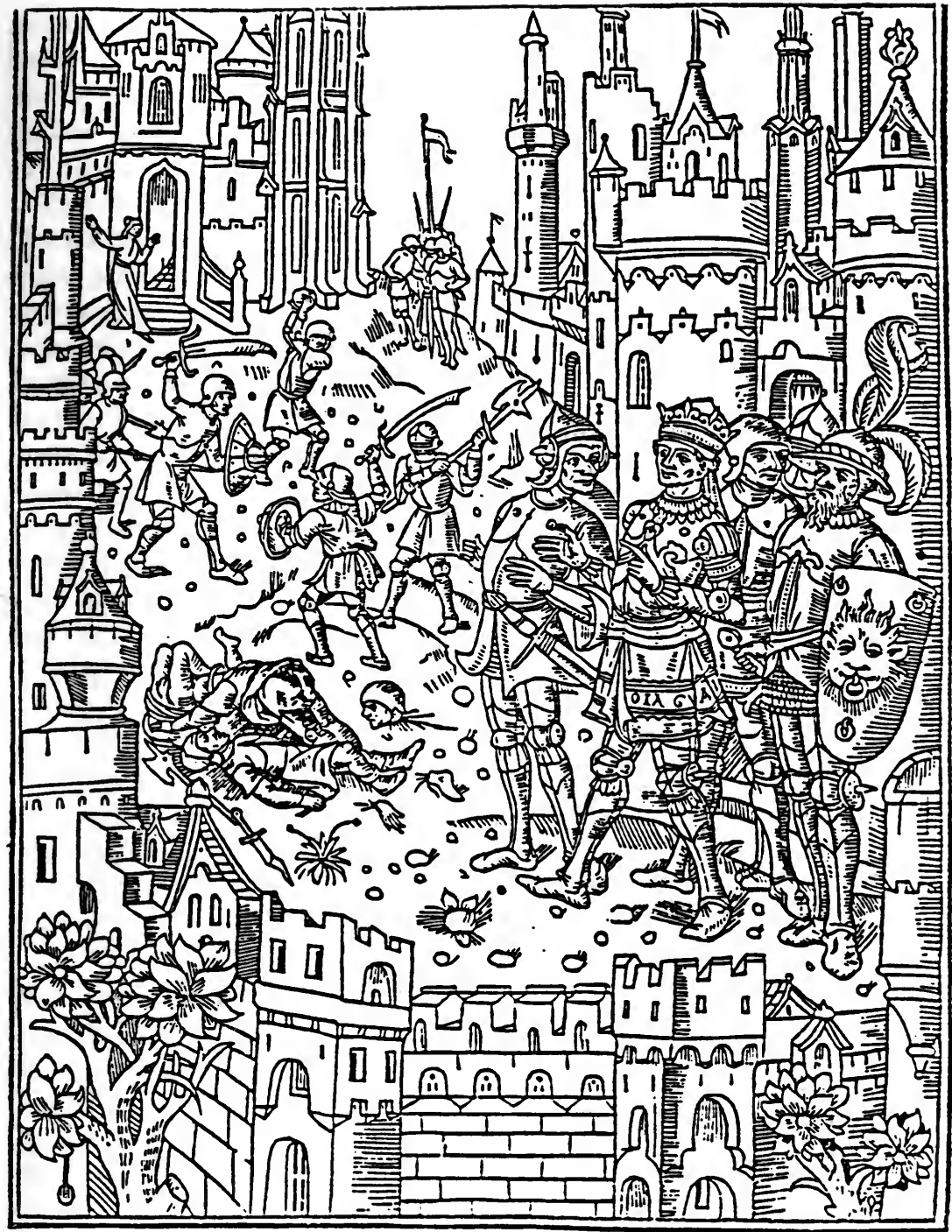

Figure 2

Le Miroir Hystorial (Paris 1495) reproduced from Ponomarenko and Roussel, op. cit., fig. 367. 
106 / Renaissance and Reformation

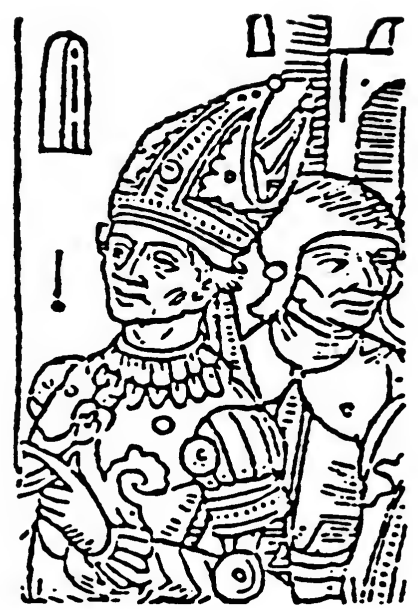

Eitat primitif : 7 dicembre 14 !).

(Josèphe, Bataille judaigue, fnc. 8 [sign. a vili] $v \%$.

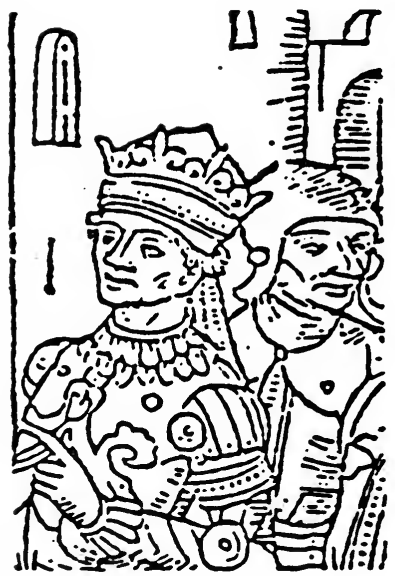

1er etat modifie: 9 juillet-to sepiembre 1493 (Clironiques de France, tome I, fol. 60 , sign. h utu, v०j.

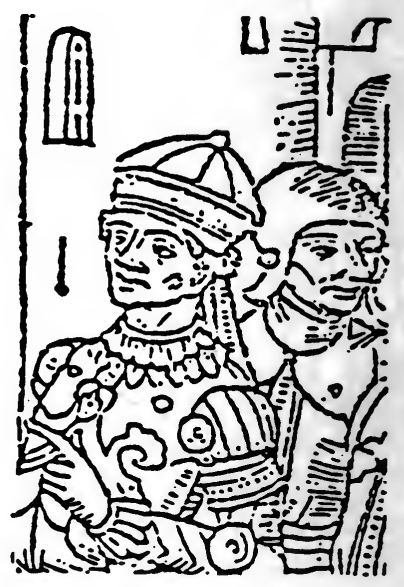

20 ctat modifie : 10r juillet 1494 (Laucciot du Lac, toine I, fol. 86 [sijn. m ri!, r•j.

Figure 3

Reproduced from André Martin, "Sur une gravure d'Antoine Verard," Revue des Livres anciens I (1914) p. 19. 
exactly cut to fit the opening and carved with the variant. For our purposes it makes little difference which method produced the variant; in either case there was a deliberate decision to use an existing composition in the works mentioned above rather than seeking a new picture to accompany a new book. At the same time that there seems to be a very low priority attributed here to the concordance of text and image, paradoxically, efforts have been made-in creating three "hats"- to assure a kind of minimal shared domain for the two media housed between the covers of a single volume.

This example is not unique. A 1498 Grüninger edition of the works of Horace includes several woodcuts that had appeared the year before in the same publisher's edition of Sebastian Brant's Narrenschiff. Here too the blocks reappear with slight but significant alterations: a woman emptying a chamber-pot from a window on the admirer who is serenading her below (in the Narrenschiff) reappears as merely a woman leaning out of the window (in the Horace), the chamber-pot having been excised from the block and replaced by a newly carved plug that continues the brick pattern of the house (Fig. 4). ${ }^{13}$ Again one must wonder how the Narrenschiff block was chosen from among Grüninger's collection, and even more why, if an effort is being made to ally picture and text, a real illustration was not provided.

In 1494 Verard published La Bible des Poetes, a French paraphrase of Ovid's Metamorphoses. The story of Arachne can easily be followed in the accompanying illustration (Fig. 5), containing two scenes: in the left background Arachne is visited by Athena in disguise; in the right foreground the loom lies overturned, Arachne, turned into a spider as punishment for her pride, contrasts sharply with the triumphant figure of Athena. It is surprising to find a woodcut so clearly tied to such a familiar story reappearing at the start of Book Seven of the Aeneid published by Verard in 1509. Book Seven, which recounts Aeneas' arrival at Latium, has no apparent connections to the themes of Arachne's tale.

In 1532 we find another paraphrase of Ovid's Metamorphoses, Le Grand Olympe des histoires poetiques (Lyon: Morin), whose pictures were brought together from several sources. Some of them were obviously cut to illustrate an Aeneid. I say obviously because the figures originally depicted were labeled with their names on the block and no one troubled to carve them flat when the block was reused. Thus, one little picture captioned "le conseil des dieux pour destruire le monde" might pass for a small divine council since it shows a figure on a throne flanked by a man on each side, were it not that the figures are still marked as being Latius, Turnus and Drantus (sic). Other blocks from the same Aeneid are scattered through the volume, sometimes as here, plausibly, sometimes completely disjunctively. In the 

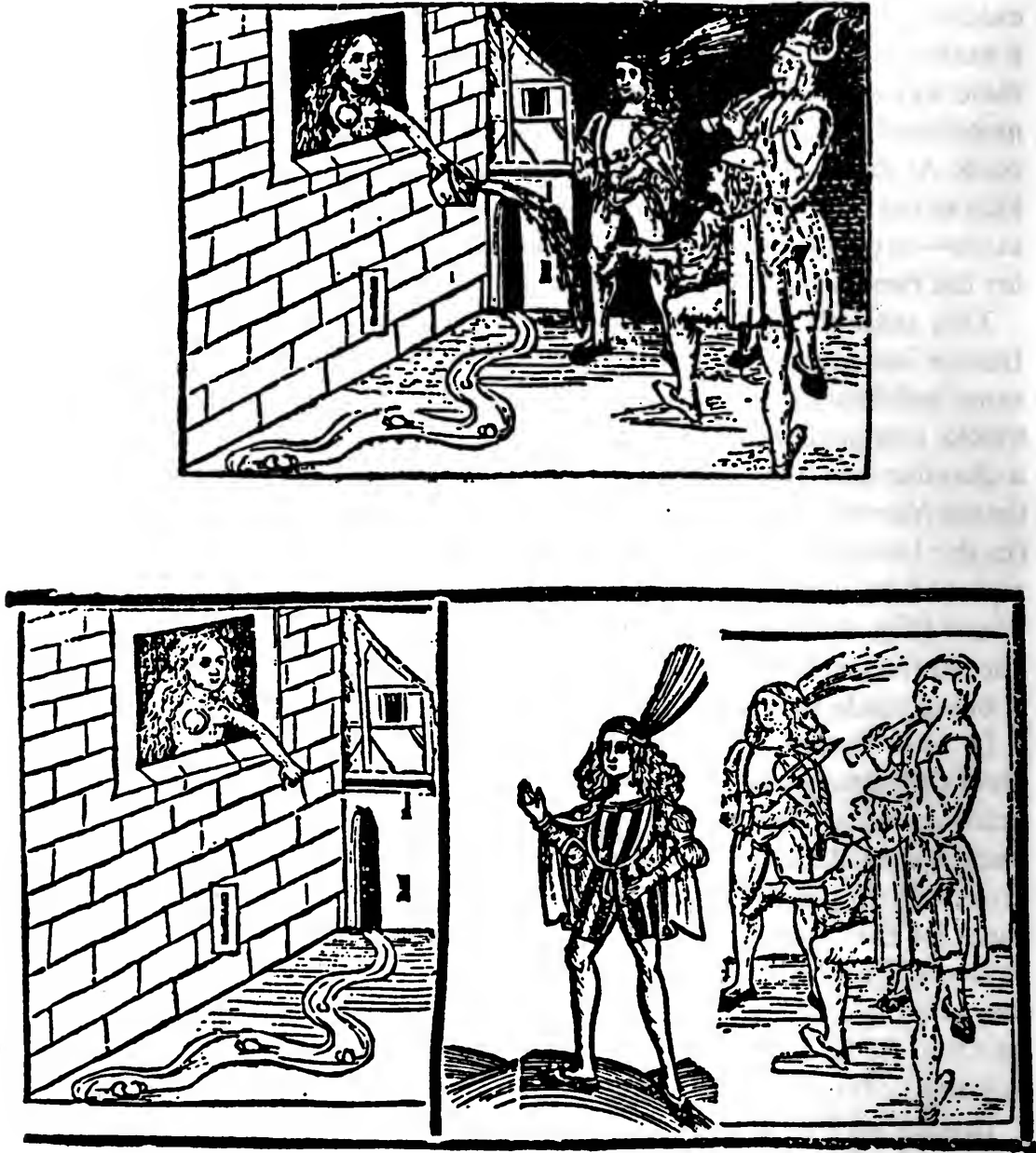

Figure 4a

Sebastian Brant, Das Narrenschiff Strassburg: Grüninger, 1494) reproduced from Loek Geeraedts, op. cit. p. 316.

Figure $4 b$

Horace Opera (Strassburg: Grüninger, 1498) reproduced from Loek Geeraedts, op. cit., p. 316.

Note that the original block has been cut into two sections with one of the figures from Gruninger's Terence placed between them. 


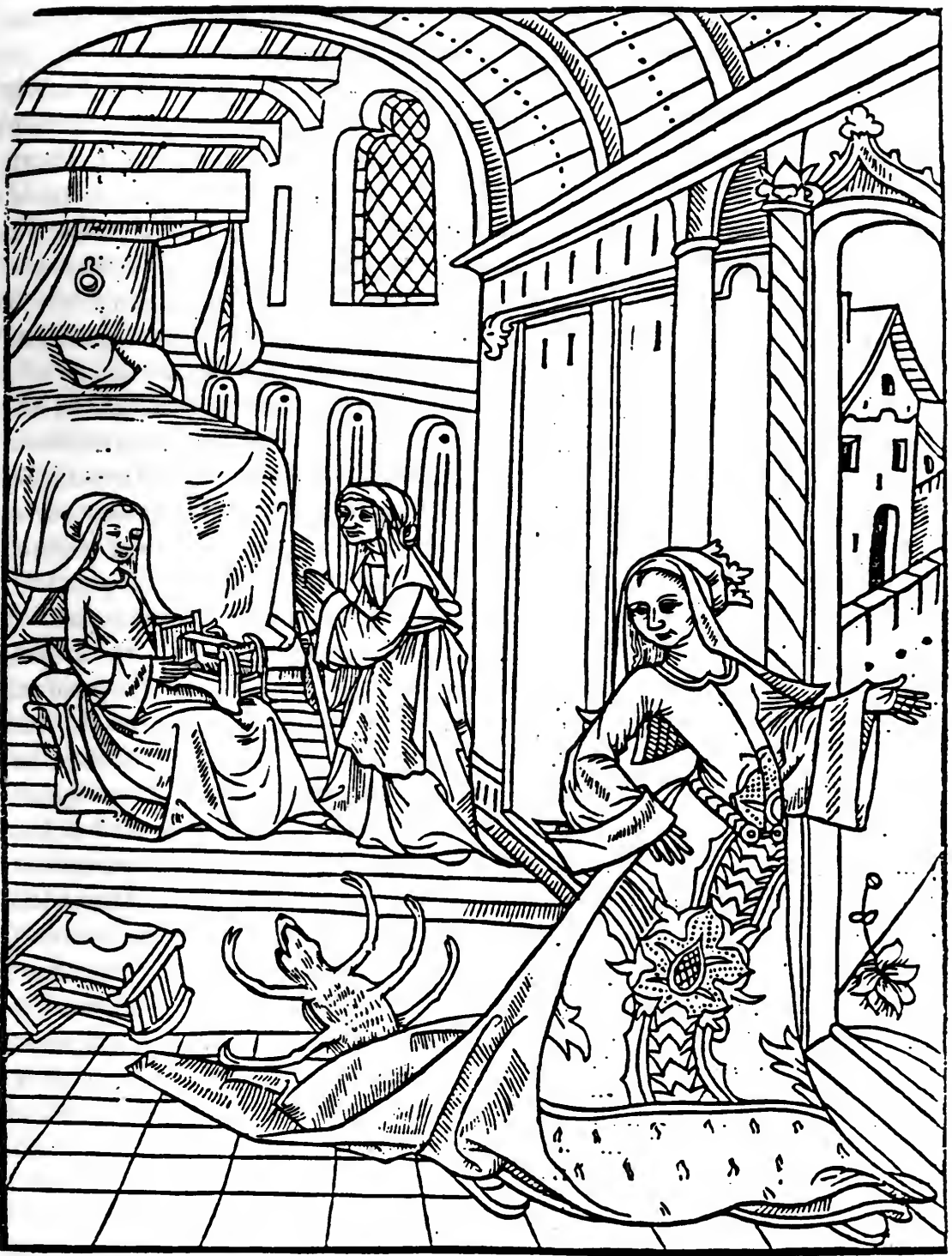

Figure 5

Arachne from The Bible des Poetes (Paris, 1494), reproduced in Ponomarenko and Roussel, op. cit., fig. 170. 
same spirit, a 1548 edition of Rabelais' Quart Livre uses blocks from some work containing the life of Achilles, for the characters are labelled Thetis, Achilles, Chyron, etc, and repeated several times (e.g. chaps. 4 and 11).

All these examples-the case of the changing hat, the disappearing chamber-pot, the tenacious Virgilian labels-attest to the degree to which the simple fact of physical existence granted special status to a block. There is some temptation to attribute this to economic forces-the desire to avoid having to pay to have a new block designed-but this is a slight savings, particularly when, as in the two cases we have just examinined, some costs of recutting had in any event to be paid. The price of producing a block was clearly subject to a number of considerations: its size (larger crack-free planks were more difficult to obtain), the complexity of its design and detail, and in a few cases, the reputation of the craftsmen involved in its production. Evidence of cutting costs is spotty and requires interpretation, but overall it suggests that the cost of cutting a new block-especially a small and simple one, as most were-was not great enough to allow us to describe the use of disjunctive pictures as primarily economically driven. Wilson (op. cit. p. 244) gives figures for the production of the heavily illustrated Archetypus Triumphantis Romae, where, in the Germany of the 1490's, woodplanks for 217 blocks cost nine florins, four pounds, ten denars, while drawing the same number of pictures on paper cost about the same. The next step, transferring the pictures to the wood, cost thirty-seven florins, although we are now, inexplicably, speaking of a total of 361 blocks, the cutting of which cost a further 148 florins. What emerges from these figures is the sense that cutting, not designing, was the most expensive part of the process. But we must not forget another important financial consideration in the early days of printing, the cost of paper itself. ${ }^{14}$ In the case of the book in question, the paper would appear to have cost between one and two florins a ream, that is, in an edition of 500 copies, the cost of the sheet of paper it was printed on would have been equal to the total cost of preparing the woodblock. ${ }^{15}$ The evidence does not suggest that any great savings accrued from reusing an existing design, or even from relatively complex modifications to an existing block (as must have been the case with the changing hats cited above). The simplest economy measure would have been to save paper costs by leaving out an image that had no particular tic to the text, and yet

Another impulse with minimal economic implictions that can be seen at work over and over again in early printed books' pictures is the tendency to respect a composition. Once it has been created, an existing design is treated as authoritative, that is, taken as the definition of how that subject 
should be displayed. When a publisher prepared to issue an edition of a work already published elsewhere, he might rent, borrow, or pirate the existing designs, or he might have them copied freely so that the new block, while it differs in style, repeats most of the elements of its predecessor, presenting them in roughly the same form and spatial arrangement. ${ }^{16}$ This respect for existing compositions echos the respect for physical objects discussed earlier, and suggests a recurrent mechanism of the habits of mind of the world we are looking at, and one that also contributed-polyvalently perhaps-to the production of disjunctive pictures. In just this way the illustrations for the first edition of Sebastian Brant's Narrenschiff (Basle: Bergman von Olpe, 1494) laid out the basic composition of illustrations found in later editions printed elsewhere in Germany, in the Low-Countries, and in England. These may appear with new woodcuts but they are closely based on the composition of those in the editio princeps, rendering the design within the limits of local craftsmanship, sometimes in mirror-image. It is as though, in a process analogous to the translation of the text into say, English, in which one must cleave to the content of the original, the pictures are being "Englished" as well (Fig. 6). ${ }^{17}$ This continues even when the ties binding text and image are broken by translation. The motto of Brant's chapter on Envy (=Neid, in German) refers to Herr Neidhard (=Mr. Envious) and the picture shows an episode in the adventures of Neidhard the Fox. While stories concerning the fox may have been familiar in other linguistic settings, the pun connecting the fox to envy, and the motto itself, ceased to exist in translation, rendering the picture disjunctive. It was nonetheless recut in England and elsewhere.

Authority of this kind preserved the title image of the Adventures of Til Eulenspiegel (depicting an owl sitting before a mirror) from edition to edition, from country to country. The image originated in Germany where it is a rebus for the name, Eulenspiegel: Eule meaning owl: Spiegel, mirror. In English, that hero was known as Howleglasse, so the image remained appropriate to the text. The image appears just as regularly in French editions although in French translations the name was Til l'Espiègle, (Til the Mischievous) capitalizing on the resemblance of sounds, reflecting Til's character, but obliterating the rebus.

Another example of continuity starts with the series of blocks created by the Strassburg publisher Gruninger for his 1496 edition of Terence. Since the plays tend to repeat a series of stock characters, old father, young lover, servant, and so forth, Grüninger had pictures representing each of these types cut on separate blocks which could then be reassembled like a pictorial alphabet to suit any given scene. In Paris Verard would seem to 
112 / Renaissance and Reformation

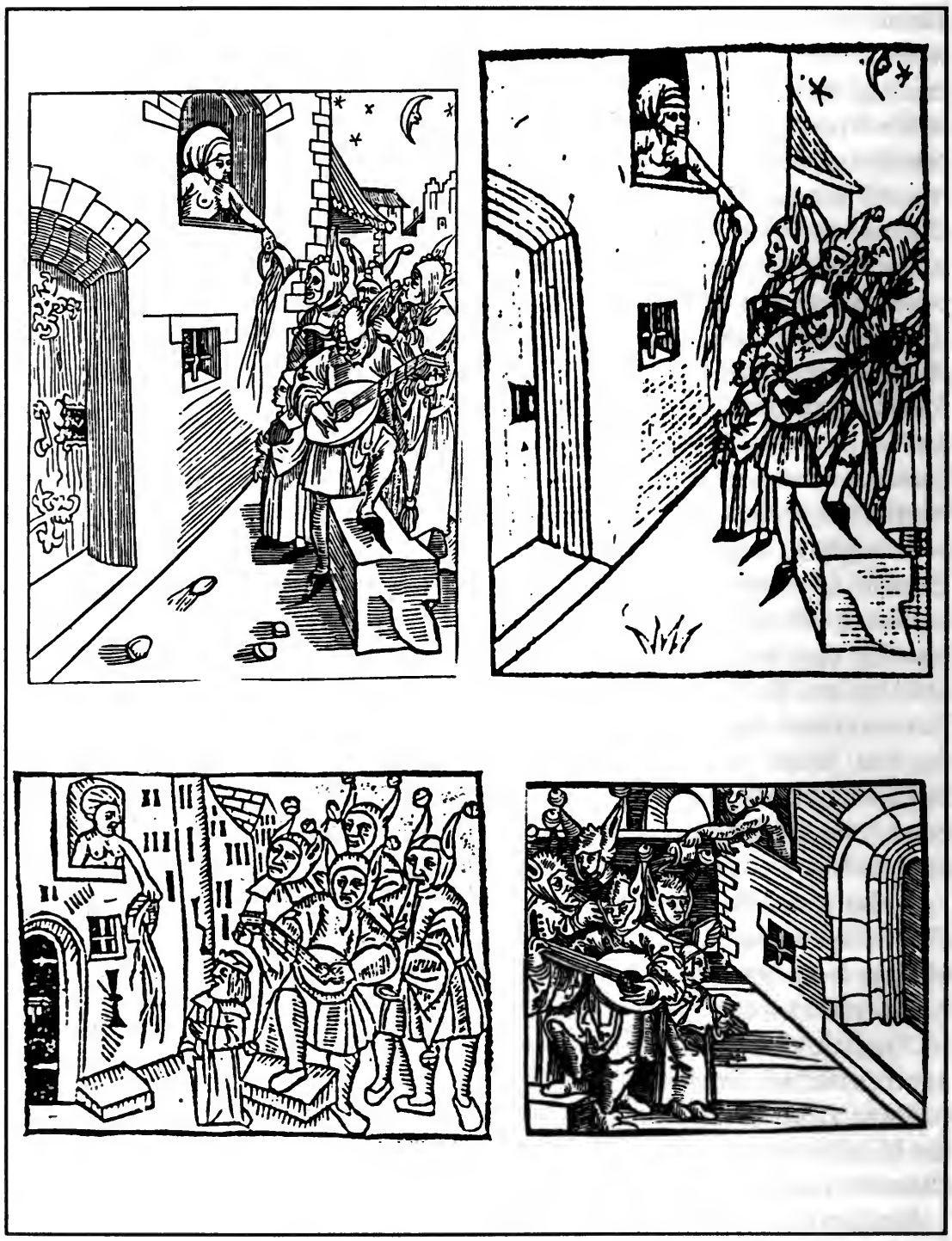

Figure 6a Facsimile of original ed. Das Narrenschiff

(Basle: Bergman von Olpe, 1494

Figure 6b London: Pynson, 1509

Figure 6c London: Wynkyn de Worde, 1509

Figure 6d Rostock, 1519. 
have copied Grüninger's clever idea, just as the Narrenschiff images had been copied: keeping the composition but producing new blocks in the local style. He also introduced an improvement: each block was morticed so that moveable type could be inserted into a carved banderole, announcing the character's name in that particular use, that is, so the picture might seem to be an illustration. Here again we have a paradox: surely the function of an illustration is to enhance, concretize, or individuate ideas presented in the text. These pictures, although created for the words they accompany, individuate only so long as the reader limits himself to one play. When the same image of a young man appears again and again, with only the letters in its banderole altered, far from particularizing, the technique would seem at best to urge the viewer to reflect on what else Terence's young lovers have in common. It is just possible that this is their purpose here, and that these pictures, by taking on an abstract quality, support the didactic value of the text for which Terence, widely used as a schoolbook, was valued.

Knowing Verard's habits, it should not surprise us that he found another use for these same pictures in the Jardin de plaisance et fleur de rhetorique (1501). Again a few minor modifications have been made to the blocks, for example, a woman's crown is changed into an elaborate hairnet. And now their banderoles identify them as allegorical personifications: Envie, Soupçon, Dangier. One is tempted to argue that such figures counterbalance the abstraction of allegory, and convey moral lessons more powerfully by attaching the allegorical personifications to physical representations. On examination, however, it is clear that no such one-to-one equivalence of woodcut to allegory exists. We find Dangier reappearing labeled Hault Vou, Envie now as a man, now a woman. Soupçon undergoes the same change (Fig. 7). The text itself adds to the disjunction. For example, on the very page bearing the block of Envie as a rather cheerful young knight, Envie is described in the text as being:
Envie la vieille enragee
Vaudoise enfumee/forcenee
Qui estoit plus laide; plus encharbonee
Quonc on ne paignist lucifer
Toutefois elle cestoit fardee
De quelque suif a cheminee
Aincoys quelle partist denfer.

("A mad old woman, damned, out of her senses, smoke covered, disfigured, uglier and blacker than Lucifer, and, what is more, bedaubed with chimney grease as she fled from hell." $)^{18}$ 
114 / Renaissance and Reformation
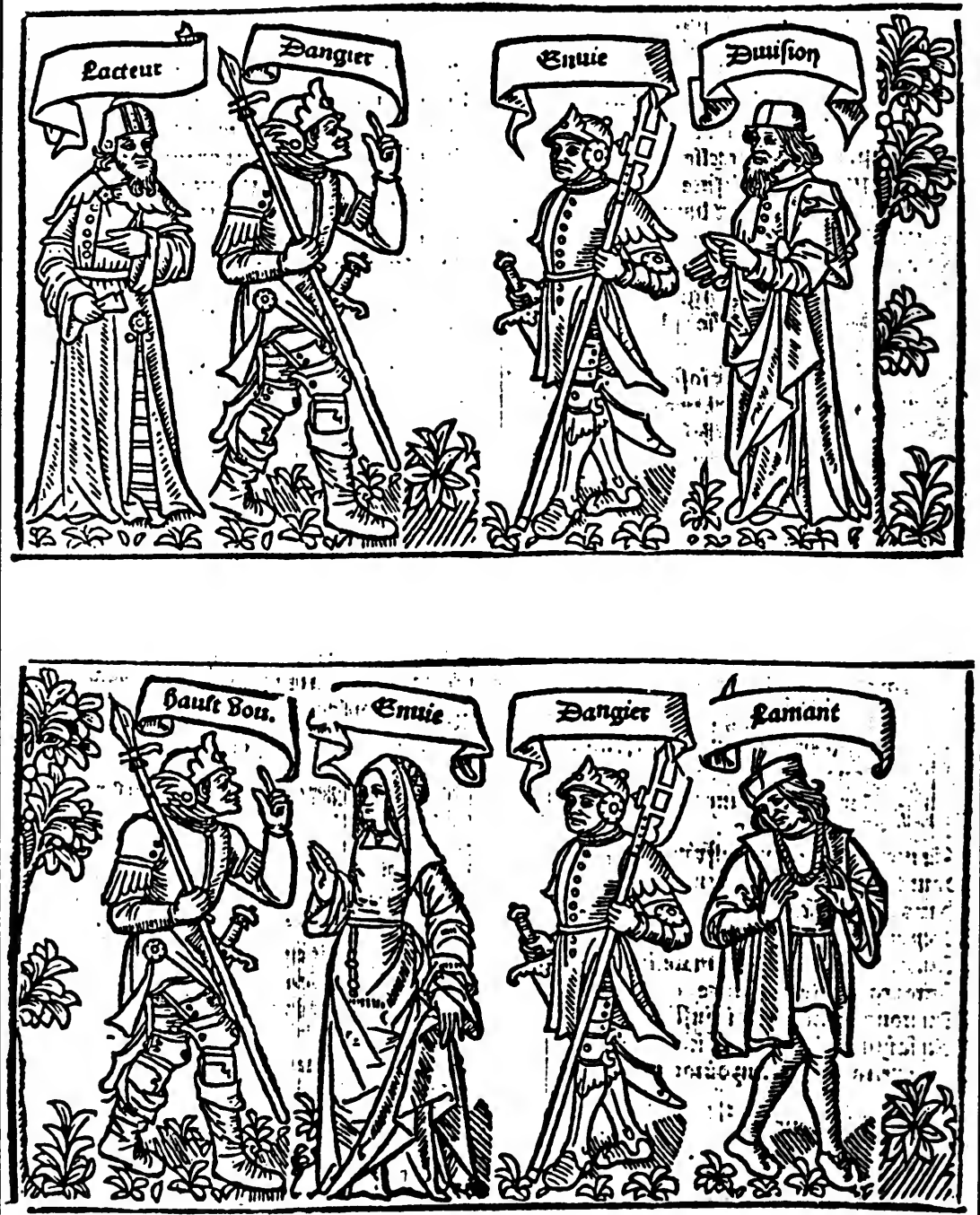

Figure 7

Le Jardin de Plaisance et Fleur de rethorique

(facsimile of Verard's 1501 ed.) sig h2v h6v. 
Verard made further use of some of these little figures (e.g., in his 1503 edition of Boccaccio's Cent Nouvelles) which reappear with what seems almost willful disjunctive effect in Galiot du Pré's 1529 edition of Virgil's Eclogues. Here too the reader is prevented from treating the pictures as representations of Virgil's shepherds: Menalaus of Eclogue II becomes Mopsus in Eclogue IV, while the former Dametus is now labelled Menalaus. Unfortunately in this instance it seems harder to find an intention, didactic or otherwise to attribute to these vagaries. It is apparent that pictures were used in a variety of ways in early printed books, most of which were of course not disjunctive at all. Some were illustrative, adding to or echoing the text; some emblematic, interacting symbiotically with the text; some allegorizing. This variety suggests once again that disjunctive pictures had multiple causes and multiple purposes.

It seems reasonable to assume these were modulated in part by the varied needs of book users in an age of low literacy. The general level of literacy for sixteenth-century Europe is not known with any reasonable accuracy. There are figures for specific groups, such as journeymen printers in Lyon in the 1580's, two thirds of whom could sign their names. ${ }^{19}$ Professionally exposed to the written word, printers likely represent a rosy view of literacy in the period. The kind of book in which disjunctive pictures are found is also the kind of book most likely to have been read aloud, communally in bourgeois or artisanal settings, or by those specially charged with reading aloud to great nobles. In this context the disjunction between text and picture may be taken as a historically specific chapter in the study of reader response. Books with pictures may have functioned as dual-purpose artifacts; the reader of the text and the viewer of the picture may not have been the same person at the same moment. "Readers" may in fact have enjoyed separately the pleasures of the text they heard from those of the pictures.

Such a model of the dual function of books is supported by the evidence of Sebastian Brant, in the preface to his Narrenschiff:

Vil narren kumen dryn

Der Bilniss ich hap har gemacht

Wer yeman der die gschrifft veracht

Oder villicht die nit kund lesen

Der siecht jm molen vol syn wesen

Und synded dar jnn wer er ist

Wem er glich sy was jm gebrist.

("There are many fools in it [=my book] whose portrait I have drawn. Either he who pays attention to the writing or he who cannot read and sees 
his nature in the picture can see who he is, whom he resembles, and what he is lacking." $)^{20}$

A literalist interpretation of this passage, although by no means the only possible one, is encouraged by the large number of the book's pictures which do seem able to stand alone or convey their message with the aid of no more than the short accompanying motto. And the non-reader whom Brant proclaims part of his intended audience may well have been included among the users of other books as well. ${ }^{20 a}$ The Latin translation of the Narrenschiff, clearly aimed at a more highly literate audience, omits this passage. But the French translation, although based on the Latin text (not Brant's original German), reintroduces a similar idea in the translator's Prologue: "Pource que les lecteurs et auditeurs de laage present sont ennuyez de veoir et ouyr longues et superflues narrations, sont aussi plaisans a lire et escouter choses sommairement en bref recitees." [Since readers and listeners of the present age are bored by seeing and hearing long and superfluous accounts, they are pleased to read and hear things summarily and briefly recited. $]^{21}$

No single interpretive system, not even one suggested by Brant's own preface can be taken as a guide to the Narrenschiff as a whole. More generally, it is important to recognize that rigorous and rigid systems systematically applied, arrangements that accord priority to unity and coherence, are not obligatory aesthetic or intellectual values in the world that produced the artifacts we are examining. In fact, the fifteenth and sixteenth centuries produced many works, some of them masterpieces, of which the unit of construction appears to be the fragment. I mean fragment here in a quite specific sense which does not question that the works are completed. Fragmentary works treat proximity as a substitute for logical connection. They are episodic. Their parts are not subordinate to the whole, nor does it seem that they are generated by an aesthetic which might treat as axiomatic our notion that the whole is greater than the sum of its parts. The gothic cathedral (work on a number of these continued through the period concerning us here) is a wonderful example of the fragmentary mode. For all its grandeur and complexity, we accept that such a building has the option of treating each architectural element as a separate problem; it is conceived in fragments. In the French literary tradition, the coq à l'ane thrives on fragments. One may wonder if Rabelais' Quart Livre would be much affected by having the order of its central episodes rearranged. The amount of scholarly ink spent to explain the rationale of the arrangements of the Essais of Montaigne suggests the fragmentary forces at work there. ${ }^{22}$ Speaking of a time roughly contemporary with the Essais, Ann Moss, 
treating material which in genre and milieu was quite different from Montaigne's, returns us to the realm of the fragment, remarking on the "discontinuous and centrifugal tendencies of Ronsard's later manner."23 The commentary, a common and often overlooked Renaissance genre, also displays a quite willful lack of cohesion, as Jean Céard has pointed out. ${ }^{24}$ From Servius to Bayle the commentary tradition presented readers with developments that take on a life of their own, separate from the ideas in the text that provoked (or served as the excuse for) their generation. Text and picture might, by this line of reasoning be considered proximate fragments, expanding the aesthetics of the fragment to the relation between the verbal and visual representation.

The issues raised by the use of disjunctive pictures are too multifarious to admit of simple answers. The adage that 'one picture is worth a thousand words' surely means to praise the concreteness, precision, and realism that can be added to a verbal discussion by a visual representation. ${ }^{25}$ Yet in early printed books, as we have seen, disjunctive images may seem to have just the opposite effect. Repetition may direct the user to consider the abstract rather than the particular, the idea of battle beyond the battle in the text, the idea of a young lover, rather than the particular travails of any given one. The persistence of an often-recopied design attests to the force of authority, or perhaps equally to the appeal of imitation as a tactic in the Renaissance. In this brief initial attempt to grant them full existence as objects worthy of study, disjunctive pictures have led us to reflect on Renaissance perceptions, aesthetics, and value systems. By observing the modes of their use, others may be prompted to go further, finding new answers and new questions.

\section{Grinnell College}

Notes

1 The expression "disjunctive pictures" is intended to signal, among other things, that the discussion following is limited to visual material with narrative pretentions, excluding elaborate initials or decorative vignettes.

2 Elizabeth Eisenstein, The Printing Press as an Agent of Change (Cambridge, England: Cambridge UP, 1979), p.258. One must admit that the level of accuracy in early printing lends immediate verisimilitude to this notion. Eisenstein does in fact seem to be troubled by the practice, since she returns to it several times, remarking that the "frugal custom" of reusing blocks "helped set pictures and words at odds with each other." I examine such frugality below.

3 The Presence of the Word (New Haven: Yale, 1967). The remark refers to manuscripts rather than printed books; although some of the technical and economic forces must differ, manuscripts do present the same disjunctive phenomena. 


\section{8 / Renaissance and Reformation}

4 Glending Olson presents a theoretical basis for this in Literature as Recreation in the Later Middle Ages (Ithaca N.Y.: Cornell, 1982). French romances frequently express the idea in their titles, e. g. L'Hystoire tres recreative des faictz et gestes du noble et vaillant Theseus de Coulogne (Paris: Longis \& Sertenas, 1534).

5 Among them Eisenstein, op. cit. p. 85., and Gerald Strauss: both comments are prompted by the pages of the Nuremburg Chronicle (Weltchronik) where, in the early editions, fewer than 650 blocks have been used repetitively to make some 1800 pictures in the text.

6 A Merlin, published by Verard in 1498 (rpt. London: Scolar, 1975) appeared with five blocks in Volume One, one used five times, three others twice; Volume Two is decorated by only a single block of a rather bloody battle scene repeated every few pages throughout the volume. These are little, perhaps trival, blocks. But two or three repetitions of a block are found even in such texts as Sebastian Brant's Narrenschiff, which clearly had blocks specially prepared for it with some care and with authorial supervision, or the 1509 translation of the Aeneid, published by Verard in which Books VIII and IX start with the same full page picture.

7 The most egregious of these, also perhaps the scholar with the greatest provocation, is the bibliographer John MacFarlane in his biography Antoine Verard (London: Bibliographical Society, 1900).

8 Also implicit in this question is the assumption that not everyone handling a book would in fact be literate, to which we shall return. Sandra Hindman touches on the same question from a different perspective in considering how illuminators, whom we have no reason to suspect were literate in the fifteenth century, managed to produced detailed illustrations of a text they themselves likely could not read. "The Roles of Author and Artist in the Procedure of Illustrating Late Medieval Texts," Text and Image, ed. David Burchmore, Acta vol. X (Binghamton, N.Y.: Center for Medieval and Early Renaissance Studies, 1986).

9 Among major works on images in early printed books are: Robert Brun, Le Livre francais illustré de la renaissance (Paris: Picard, 1969); Arthur Hind, An Introduction to the History of the Woodcut (New York: Dover, 1963; rpt. of 1935 ed.); Sandra Hindman ed., Early Illustrated Books (Washington, D.C.: Library of Congress, 1982); William Ivins, Prints and Visual Communication (Cambridge, Ma.: MIT Press, 1953); André Martin, Le livre illustré en France au XV siècle (Paris: Alcan, 1931); Michel Pastoureau, "L'Illustration du livre: comprendre ou rêver?" L'Histoire de l'édition française, vol. I, ed. Rogier Chartier and Henri-Jean Martin (Paris: Promodis, 1982); Alfred W. Pollard, Early illustrated Books (London: Dutton, 1917); Lisa Ponomarenko and André Roussel, La Gravure sur bois d travers 69 incunables et 434 gravures (Paris: Les Yeux Ouverts, 1970).

10 Robert Brun (op. cit. p. 12) goes so far as to suggest that many of the marks interpreted as makers marks are in fact the "brands" of owners or publishers.

11 An example of a block used in more and more worn condition can be found in Adrian Wilson, The Making of the Nuremberg Chronicle (Amsterdam: Nico Israel, 1976), p.187. Many sixteenth-century blocks found their way into the possession of publishers of popular imprints, the Garniers or Oudots of Troyes, where they were used until they no longer produced a recognizable pattern on the page, well into the eighteenth century.

12 The variant of this block was first noted by Andre Martin, "Sur une Gravure d'Antoine Verard," Revue des Livres anciens, I(1914),15-20. Martin interpreted the alterations as following in simple chronological sequence and used them to date the undated Bible historiée. As is clear from the foregoing discussion, cases of the block's use not known to Martin vitiate its use for dating. 
13 My attention was drawn to this reuse by Loek Geeraedts, "Die Strassburger Augaben und ihre Holzschnitte," Philobiblion, 24 (1980) 299-327. The woodcut in question accompanies Ode Ten of Book Three, "Ad Lycen," as well as the Second Satire.

14 See Paul Mellottée, Histoire économique de l'imprimerie, (Paris: Hachette, 1905), and Lucien Febvre and Henri-Jean Martin, L'Apparition du Livre (Paris: Albin Michel, 1958), pp. 167-72.

15 Leon Voet, The Golden Compasses (Amsterdam: Van Gendt, 1972), pp.223-225, gives data for the production of woodcuts for the Plantin press in the 1560's and 1570's when, for example, the 72 cuts in an octavo Reynard the Fox cost 30 florins to design and 54 to cut. Marianne Grivel, "La réglementation du travail des graveurs en France," Le Livre et l'image en France au XVT⿱e siècle (Paris: Presses de l'Ecole normale supérieure, 1989), p. 14-15, gives similar figures for France in the 1540's and 1550's.

16 See Fig. 6. See also Laurence Harf-Lancner, "L'Illustration du roman de Melusine de Jean d'Arras dans les éditions du XVe et du XVI ${ }^{e}$ siècle," Le Livre et l'image en France au XVI siècle (Paris: Presses de l'Ecole normale supérieure, 1989), pp. 10-29. Alfred Pollard, Early Illustrated Books (London: Dutton, 1917), p. 145, remarks on the reuse of woodcuts from Du Pré's 1483 edition of Boccaccio's De la Ruine des nobles hommes et femmes, in its translation into English by Lydgate published by Pynson in 1494. Fr. Bourdillon, "Some Notes on Two Early Romances, Huon de Bordeaux and Mélusine," The Library, 4th series, I (1920) 21-40, traces woodcuts originally appearing in Millet's Destruction de Troye to Le Noir's 1513 Huon, and again in Janot's edition (after 1532) where they appear as mirror images; the same composition is used again in the Huon of Jean Bonfons (1547-68) in its original orientation-either because Bonfons too had had the blocks copied directly or because he had access to Le Noir's material. Another such series mentioned by Rudolf Hirsch (Printing, Selling, Reading [Wiesbaden: Harrasowitz, 1967], p. 49), which I have not seen, involves the reuse and recopying of the illustrations of Zainer's 1473 edition of Boccaccio's De Claris Mulieribus in later editions appearing in Augsburg, Louvain, and Saragossa. Two German translations of the Celestina were published $(1520,1534)$ with different endings; both use the same woodblocks, although they no longer coincide with events recounted in the second version of the story: see Die Celestina Übersetzungen von Christof Wirsung, ed. Kathleen Kish and Ursula Ritzenhof (Hildesheim, 1984). For other examples, see below.

17 The Strassburg woodcut in figure 4a is yet another in this series. @NOTES $=18$ Le Jardin de plaisance et fleur de rhetorique (Paris: Société des Anciens Textes Français, 1910), (facsimile of Verard's 1501 edition) h2 v.

19 For further commentary on sixteenth-century readers and communal reading, see Natalie Z. Davis, "Printing and the People," Society and Culture in Early Modern France (Stanford: Stanford UP, 1975).

20 Ed. Franz Schulz (Strassburg: Jahresgaben der Gesellschaft für Elsäsische Literatur, 1913), p.4. A facsimile reprint of the first edition.

20aAnnabel Patterson Pastoral and Ideology: Virgil to Valery (Berkeley: University of California Press, 1987) Giles Brant's introduction to Grüninger's 1502 Virgil: "Hic legere historias commentaque plurimus doctus: $/ \mathbb{N}$ minus indoctus parleger illa potest." "While the commentary is designed for the learned, the volume is equally, through the illustrations, accessible to the unlearned." Patterson goes on to represent the illustrations as a "running gloss on the text of Virgil by providing a visual equivalent, in either narrative or symbolic form, for as many of the elements of the text as the artist could manage to incorporate into any single design" pp. 92-93.

21 La Grand Nef des folz du monde (Lyon: Fr. Juste, 1530) a 3 r. 
22 Examples of this critial approach among modern scholars can be seen inter alia in Lawrence Kritzman, Destruction/Descouverte: Le fonctionnement de la rhétorique dans les ESSAIS de Montaigne (Lexington Kentucky: French Forum, 1980), esp. pp. 11-12; John Holyoake, Contextual and Thematic Interference in Montaigne's ESSAIS (Sheffield: Sheffield Academic Press, 1986).

By the end of the sixteenth century, the era of the fragment was over. Thus Estienne Pasquier, a great admirer of Montaigne's, calls the Essais a masterpiece and yet points out: "Vous touverez en luy plusieurs chapitres dont le chef ne se rapport aucunement à tout le demourant du corps, fors aux pieds. Et sur tous, celuy Des Vers de Virgil, qu'il pouvoit à meilleur compte intituler Cocq à l'Asne; pour s'estre donné pleine liberté de sauter d'un propos à autres." Choix de Lettres, ed. D. Thickett (Geneva: Droz, 1956), p.53.

23 Poetry and Fable (Cambridge England: Cambridge UP, 1984), p. 148.

24 "Transformations du commentaire," L'Automne de la Renaissance, XXII' Colloque international d'études humanistes (Tours, 1979), ed. Jean Céard, (Paris: Vrin, 1981).

25 This idea is expressed in Renaissance terms by Erasmus in Adagia I, i, 100: "Oculis magis habenda fides, quam auribus." 